Disclosure of Interests: None declared

DOI: 10.1136/annrheumdis-2021-eular.413

\section{AB0815 1 FIRST DEGREE RELATIVES OF PATIENTS WITH SYSTEMIC LUPUS ERYTHEMATOSUS - CLINICAL, SEROLOGICAL AND IMMUNOLOGICAL CORRELATIONS}

B. Penev ${ }^{1}$, G. Vasilev' ${ }^{2}$, D. Kyurkchiev ${ }^{3}$, S. Monov ${ }^{4} .{ }^{1}$ St Anna University Hospital, Internal Medicine, Sofia, Bulgaria; ${ }^{2}$ St. Ivan Rilski University Hospital, Laboratory of Clinical Immunology, Sofia, Bulgaria; ${ }^{3}$ St. Ivan Rilski University Hospital, Laboratory of Clinical Immunology, Sofia, Bulgaria; ${ }^{4}$ St. Ivan Rilski University Hospital, Rheumatology Clinic, Sofia, Bulgaria

Background: Antinuclear antibodies (ANA) have been unequivocally recognized as essential for diagnosis and play both pathogenic and diagnostic roles in systemic lupus erythematosus (SLE). SLE and ANA have also been found to be more often among relatives of SLE patients. ANA and other immunological changes are known to appear prior to the clinical onset of the disease and thus can be used as predictors. Studies have reported that relatives of SLE patients who later transitioned to SLE displayed more lupus-associated autoantibody specificities and had early clinical signs. They also displayed elevated baseline plasma levels of inflammatory mediators, including B-lymphocyte stimulator (BLyS) and interferon-associated chemokines, with concurrent decreases in levels of regulatory mediators, e.g. tumor growth factor (TGF)- $\beta$. Commonly recognized risk factors for SLE are signs of past Epstein-Barr (EBV) infection, use of estrogen drugs and current smoking. It seems that ANA, immunologic changes and risk factors have not been investigated together in relatives of SLE patients. Objectives: The aim of the study was to determine the relative prevalence of clinical signs of SLE or connective tissue disease (CTD), smoking, use of estrogen drugs and levels of circulating ANA, BLyS, IFN- $\alpha$, TGF- $\beta$, anti-EBV viral capsid antigen (VCA) IgM and IgG antibodies among sera of FDR, non-FDR healthy individuals and SLE patients.

Methods: Forty three FDRs of SLE patients were studied along with 15 SLE patients and 15 clinically healthy subjects as control groups. The FDRs and the healthy answered a questionnaire about early clinical signs of CTD, smoking and estrogen use history. The questionnaire was developed based on the existing Screening Questionnaire for Connective Tissue Diseases and current knowledge of most early signs of CTD. Blood samples were obtained and tested for ANA, both by indirect immunofluorescence and immunoblot, anti-dsDNA by ELISA. ELISA was also performed to measure levels of BLys, IFN- $\alpha$, TGF- $\beta$, anti-EBV IgM and IgG. Results: More than half of the FDRs displayed ANA in titer 1:160 or more, with predominately AC-4 type of fluorescence according to International Classification on ANA Patterns (ICAP) compared to only AC- 1 and AC-0 among patients and controls respectively. A correlation between the ANA titer and the number of complaints was found. This was particularly valid or reported skin complaints and oral ulcers which appeared more frequently when ANA was $1: 320$ or above $(p=0,018$ and 0,038 respectively). Furthermore, oral ulcerations showed positive correlation with the presence of anti-Ro60. No associations were found in the healthy group between reported complaints and ANA titers. Smoking and estrogen use did not differ across the three groups. Patients showed significant differences in levels of BLys $(p=0,027)$, TGF- $\beta(p=0,019)$ and anti-EBV IgG $(p=0.041)$ compared to both FDRs and controls. Without reaching statistical significance, levels of TGF- $\beta$ tend to split the FDR group into "healthy-like" and "SLE-like".

Conclusion: Our results show that FDR ANA levels are between those of SLE patients and healthy subject groups. This is consistent with previous studies. The data also suggest that ANA positivity correlates with reported complaints, some of which could be interpreted as very early clinical signs of SLE. Of note, anti-Ro60 is known to be among the earliest ANA that appear in "future" SLE patients and in this study they are related to oral complaints that could be caused by early sicca phenomena. Immunologically, our data support previous findings [1] that the FDRs are a heterogenic group with different "lupus-developing" potential. REFERENCES:

[1] Munroe ME. et al, Soluble Mediators and Clinical Features Discern Risk of Transitioning to Classified Disease in Relatives of Systemic Lupus Erythematosus Patients, Arthritis Rheumatol. 2017 March; 69(3): 630-642.

Disclosure of Interests: Bogdan Penev: None declared, Georgi Vasilev: None declared, Dobroslav Kyurkchiev: None declared, Simeon Monov Speakers bureau: I have been paid for giving lectures on statistical data on efficacy of many pharmaceutical products on various companies

DOI: 10.1136/annrheumdis-2021-eular.511

\begin{tabular}{|l|l|}
\hline AB0816 & PREDICTORS OF RESPONSE TO THE FIRST \\
BDMARD IN BIOLOGIC-NAÏVE PATIENTS WITH \\
SPONDYLOARTHRITIS: A COHORT STUDY
\end{tabular}

B. M. Fernandes ${ }^{1}$, S. Garcia ${ }^{1}$, F. Oliveira Pinheiro ${ }^{1}$, M. Rato ${ }^{1}$, D. Fonseca ${ }^{2}$, D. Santos Oliveira ${ }^{1,3}$, A. Martins ${ }^{1}$, F. R. Martins ${ }^{4}$, M. Bernardes ${ }^{1,5}$, L. Costa ${ }^{1}$
${ }^{1}$ Centro Hospitalar Universitário São João, Rheumatology, Porto, Portugal; ${ }^{2}$ Centro Hospitalar Vila Nova de Gaia/Espinho, Rheumatology, Vila Nova de Gaia, Portugal; ${ }^{3}$ Faculty of Medicine, University of Porto, Center for Health Technology and Services Research (CINTESIS), Porto, Portugal; ${ }^{4}$ Centro Hospitalar Universitário do Algarve, Rheumatology, Faro, Portugal; ${ }^{5}$ Faculty of Medicine, University of Porto, Departamento de Medicina, Porto, Portugal

Background: Several markers of response to biologic disease-modifying antirheumatic drugs (bDMARDs) have been identified in Rheumatoid Arthritis. However, data on predictors of response in Spondyloarthritis (SpA) are more limited. Objectives: To identify predictors of response to bDMARDs in a SpA population. Methods: Monocentric retrospective study including all the SpA patients (ASAS classification criteria) followed at our Rheumatology Department, registered in the national database and treated with bDMARD between July 2001 and August 2020. Demographic, clinical and laboratorial data at baseline and disease activity measures at 6 and 12 months of bDMARD were collected. Mann-Whitney $U$ test and chi-square tests were used to the comparison analysis between groups (continuous and categorical variables, respectively) and univariate logistic regression was used in the prediction analysis.

Results: A total of 325 patients were included, $178(54.8 \%)$ males, $76(23.4 \%)$ smokers and $164(50.5 \%)$ HLA-B27 positive. Concerning SpA subtypes: 236 (72.6\%) had Ankylosing Spondylitis, 31 (9.5\%) had Inflammatory Bowel Disease Associated SpA and $58(17.9 \%)$ had Undifferentiated SpA. The mean age at the start of the first bDMARD was 41.7 years $( \pm 12.2)$ and the median disease duration was 12.1 years (0.5-52.7). The mean ASDAS-CPR (Ankylosing Spondylitis Disease Activity Score with C-reactive protein) was $4.0( \pm 0.8)$ and most patients (57.2\%) exhibited very high disease activity at baseline as evaluated by ASDASCRP. Ninety-five (29.2\%) patients were taking NSAIDs (nonsteroidal anti-inflammatory drugs) and 131 (40.3\%) were under csDMARDs (conventional synthetic disease-modifying antirheumatic drugs), being sulfasalazine the most frequent (28.3\%). All patients started iTNF (tumor necrosis factor inhibitors): adalimumab $(30.2 \%)$ and golimumab $(24.6 \%)$ were the most frequently started bDMARDs. At 6 and 12 months of bDMARD, $63.5 \%$ and $65.7 \%$ of the patients had ASDAS response (clinically important improvement or major improvement). Variables that showed statistically significant differences at baseline between those different groups are presented at Table 1.

Table 1. Baseline characteristics that showed statistically significant differences at baseline between groups of patients with vs without ASDAS responses at 6 and 12 months of bDMARD. (bDMARD: biologic disease-modifying antirheumatic drug; BMI: body mass index; CRP: C-reactive protein; ESR: erythrocyte sedimentation rate).

\begin{tabular}{|c|c|c|c|c|c|c|}
\hline & \multicolumn{3}{|c|}{ ASDAS response at 6 months } & \multicolumn{3}{|c|}{ ASDAS response at 12 months } \\
\hline & yes & no & $\mathrm{p}$-value & yes & no & $\mathrm{p}$-value \\
\hline $\begin{array}{l}\text { Age at start of } \\
\text { bDMARD } \\
\text { (mean } \pm \text { SD) }\end{array}$ & $\begin{array}{c}39.6 \pm 12.2 \\
\text { years }\end{array}$ & $\begin{array}{c}44.2 \pm 10.7 \\
\text { years }\end{array}$ & $p=0.012$ & $\begin{array}{c}40.7 \pm 12.8 \\
\text { years }\end{array}$ & $\begin{array}{c}44.2 \pm 10.9 \\
\text { years }\end{array}$ & $\mathrm{p}=0.035$ \\
\hline $\begin{array}{l}\text { Age at SpA diagno- } \\
\text { sis }(\text { mean } \pm S D)\end{array}$ & $\begin{array}{c}32.2 \pm 11.1 \\
\text { years }\end{array}$ & $\begin{array}{c}35.8 \pm 11.9 \\
\text { years }\end{array}$ & $p=0.023$ & $\begin{array}{c}31.3 \pm 10.7 \\
\text { years }\end{array}$ & $\begin{array}{c}35.4 \pm 11.2 \\
\text { years }\end{array}$ & $\mathrm{p}=0.010$ \\
\hline BMI (mean \pm SD) & $\begin{array}{r}25.7 \pm 4.3 \\
\mathrm{~kg} / \mathrm{m}^{2}\end{array}$ & $\begin{array}{r}28.7 \pm 6.0 \\
\mathrm{~kg} / \mathrm{m}^{2}\end{array}$ & $p=0.045$ & $\begin{array}{r}25.6 \pm 4.3 \\
\mathrm{~kg} / \mathrm{m}^{2}\end{array}$ & $\begin{array}{r}28.5 \pm 5.7 \\
\mathrm{~kg} / \mathrm{m}^{2}\end{array}$ & $p=0.005$ \\
\hline CRP $($ mean $\pm S D)$ & $\begin{array}{r}3.2 \pm 3.5 \\
\mathrm{mg} / \mathrm{dL}\end{array}$ & $\begin{array}{r}1.1 \pm 1.2 \\
\mathrm{mg} / \mathrm{dL}\end{array}$ & $p<0.001$ & $\begin{array}{r}3.4 \pm 3.5 \\
\mathrm{mg} / \mathrm{dL}\end{array}$ & $\begin{array}{r}1.4 \pm 1.6 \\
\mathrm{mg} / \mathrm{dL}\end{array}$ & $p<0.001$ \\
\hline ESR $($ mean $\pm S D)$ & $36 \pm 22$ & $25 \pm 20$ & $p<0.001$ & $38 \pm 24$ & $27 \pm 17$ & $p=0.001$ \\
\hline $\begin{array}{l}\text { ASDAS-CRP } \\
(\text { mean } \pm S D)\end{array}$ & $4.1 \pm 0.8$ & $3.5 \pm 0.4$ & $\mathrm{p}<0.001$ & $4.2 \pm 0.8$ & $3.6 \pm 0.8$ & $p<0.001$ \\
\hline HLA-B27+ & $61.5 \%$ & $26 \%$ & $p=0.006$ & $60.1 \%$ & $44.4 \%$ & $p=0.033$ \\
\hline Males & $62.3 \%$ & $35.7 \%$ & $p=0.004$ & $62.3 \%$ & $37.5 \%$ & $p=0.001$ \\
\hline
\end{tabular}

Body mass index (BMI) (OR 0.89 [0.80-0.99], 95\% Cl) and ASDAS-CRP at baseline (OR 2.8 [1.2-6.6], 95\% Cl) predicted ASDAS response at 6 months; moreover, only BMI (OR 0.91 [0.83 0.99 ], $95 \% \mathrm{Cl}$ ) predicted ASDAS response at 12 months of bDMARD.

Conclusion: Our results demonstrate that a higher baseline disease activity predicts the response to bDMARDs in SpA. Interestingly, BMI at baseline also predicts ASAS response at 6 and 12 monthes of treatment with bDMARD, in line with some data that suggest an association between BMI and disease activity in SpA.

Disclosure of Interests: None declared

DOI: 10.1136/annrheumdis-2021-eular.921

AB0817

CAN RHEUMATIC CONDITIONS ASSOCIATED INTERSTITIAL LUNG DISEASES BE MANAGED IN A DISTRICT GENERAL HOSPITAL - RESULTS FROM A LONGITUDINAL OUTCOMES SURVEY

A. Francioni ${ }^{1}$, J. Gnanapragasam ${ }^{1}$, N. Ramsundar ${ }^{1}$, V. Joshi ${ }^{1}$, M. K. Nisar ${ }^{1}$ ${ }^{1}$ Luton and Dunstable University Hospital, Rheumatology, Luton, United Kingdom 